\title{
TITLE INDEX OF VOLUME 14
}

\section{EDITORIALS}

\section{LETTERS TO THE EDITOR}

\section{UNITED NATIONS ACTIVITIES}

\section{UN / GA}

- The 'Question of Antarctica'

UN

- The World Commission on Environment and Development

UNEP

- Harmful Chemicals in Trade - Expert Meeting Reconvened

- Pollution From Land-based Sources

- Ozone Convention Signed

- UNEP Governing Council -.. A Preview of the Papers

Export of Potentially Harmful Chemicals - Recent Developments (Eckard Rehbinder)

- The Governing Council - Thirteenth Session

- Executive Director's Reports

Extracts from Statements

Committee of the Whole

Intergovernmental Inter-sessional Preparatory Committee

The Closing Session

UN / ECE

- Senior Advisors Meet

Pollution From Land-based Sources

UNCTAD

- Tropical Timber Agreement in Force

ESCAP

- Legal Aspects of Programme (Amado S. Tolentino, Jr.)

The Draft Regional Seas Agreement for East Africa

- Environment in Asia

PREP-COM and LOS-Tribunal Begins Third Session

\section{OTHER INTERNATIONAL DEVELOPMENTS}

- Qui Assure la Conservation de l'Environnement dans l'Antarctique (Alexandre Kiss)

\section{OECD}

- Transfrontier Movements of Hazardous Wastes - An Examination of the Council Decision and Recommendation (Henri Smets)

International North Sea Conference

EC

- European Council

Nitrogen Dioxide Directive Adopted

Council of Environment Ministers

Council Directive on Lead in Petrol

EP

- Waste Salts in Alsace

Consultations between States on the Quality of Fresh Waters that Can Support Fish Life

Committee on Ecology and Development

$1,37,85$

1,37
$37 \quad$ EC

- Pollution from Large Combustion Plants

- Modification of Waste Oil Directive Proposed

EP

- Resolutions on Bhopal Disaster

CE

- First Conference of Mediterranean Regions

\section{NATIONAL AFFAIRS}

Canada

- Seals Enquiry Starts its Work

Latin American Journal Established

Germany, Fed. Rep. of

- Basic Questions Concerning the Law of Nature Protection (Hermann Soell)

Japan

- Whalers to Defy Ban

USA

- Conservation and the Abrogation of Hunting Rights in U.S./Indian Treaties (Malcolm J. Foster)

\section{SELECTED DOCUMENTS}

- World Commission on the Environment and Development (Statements of the Chairman, Mrs. Gro Harlem Brundtland)

IUCN General Assembly
- Recommendation and Resolution on Antarctica International Conference on the Protection of the North Sea (Declaration and Conclusions)

OID

The Bonn Economic Declaration

Ozone Convention - Final Act of the Conference of Plenipotentiaries on the Protection of the Ozone Layer

Vienna Convention for the Protection of the Ozone Layer

UNEP

- Protection of the Marine Environment Against Pollution from Land-based Sources - Montreal Guidelines

Royal Commission on Seals and Sealing

UNEP / GC 13

- Decisions (Selection)

- Reform of the Information Service

- World Climate Programme

- Marine Pollution

- Soils

- Desertification

- Environmental Law

I. Protection of the Ozone Layer

II. Protection of the Marine Environment Against Pollution from Land-based Sources

III. Other Topics of the Montevideo Programme for the Development and Periodic Review of Environmental Law 
A. Environmentally Sound Management of Hazardous Wastes

B. Exchange of Information on Potentially Harmful Chemicals (in Particular Pesticides) in International Trade

C. Environmental Impact Assessment

IV. Shared Natural Resources

V. Convention on the Conservation of Migratory Species of Wild Animals

VI. International Conventions and Protocols in the Field of the Environment

- Energy

- Water

- State-of-the-Environment Reports in the Developing Countries

- Environmental Education and Training in Africa

- Preparation of National Conservation Strategies

- International Meeting on Environmental Education and Training

- International Register of Potential Toxic Chemicals
- Implementation of the Action Plan for Biosphere Reserves

- Developing a Strategy for the Programme Budget of UNEP for 1988-1989

- Suggested Format for the Presentation of the 1988-1989 Programme Budget

- Environmental Training Network

- Programme Budget of UNEP 1986-1987

- Co-operation with Non-Governmental Organizations

- Israel's Decision to Build a Canal Linking the Mediterranean Sea to the Dead Sea

- Impacts of A partheid on the Environment

- Environment Fund $\quad 116$

- Programme Policy and Implementation 116

- State-of-the-Environment Reports 117

- Environment and Financial Institutions 118

- Trust Funds 120

- Programme and Programme Support Costs 120

- Additional Sources of Funding 120

\section{AUTHOR INDEX OF VOLUME 14}

Forster, Malcolm J., 67

Harlem Brundtland, Gro, 26

Kiss, Alexandre, 52

Rehbinder, Eckard, 48
Smets, Henri, 16

Soell, Hermann, 58

Tolentino, Amado, S., Jr., 10 